\title{
Religious Communication of Sunni-Shi'i in Resolving Internal Religion Conflict in North Sumatra
}

\author{
Hasyimsyah Nasution' ${ }^{1}$, Suwardi Lubis ${ }^{2}$, Abdul Khalik ${ }^{3}$ \\ ${ }^{1,2,3}$ Universitas Islam Negeri Sumatera Utara, Indonesia
}

\section{Abstract}

The purpose of this study was to find and study about model religious communication and Sunni-Syi'i Conflict in Social Media in Making Harmonist Relationships in North Sumatera. This research will start from the interpretive paradigm. In this paradigm view, human beings are "impossible not to communicate". The result shows that Since the beginning of their respective existence, religious communication between Sunni-Shi'is in North Sumatra has always experienced ups and downs in accordance with the existing context in the region. Following the fatwa from the Center, all Islamic organizations in North Sumatra, both NU, Muhammadiyah and Al Washliyah as the oldest Islamic organizations, as well as more recent Islamic organizations such as An Nas, which are Sunnah, agree to state that Shi'ism is a religious understanding who are perverted / deviant. However, based on existing political trends, after the Reformation, slowly the views of Sunni Islamic Organizations began to shift. This shift in view also follows the fatwa of the leadership of the mass organizations at the central level, along with the constellation of religious relations in the Islamic world, even though the shift is taking place gradually. The more moderate NU argues that the non-ghulat Syi groups are not heretical, even though grassroots congregations still view all Shi'i ideas as deviant / deviant, because information does not spread quickly and evenly.

\author{
Keywords \\ organizational culture; \\ transformational leadership, job \\ satisfaction; work motivation; \\ performance
}

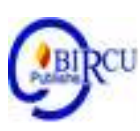

\section{Introduction}

For a long time in the archipelago, conflicts of understanding, to social friction and culminating in physical conflicts between Islamic religious schools, is a story that has continued to occur and has continued over time. The religious understanding of Islam in the archipelago which is dominated by Ahlus Sunnah Wal Jamaah (Aswaja) or widely known as Sunnah / Sunni has always been faced with other Islamic religious ideas that are deemed incompatible with this dominant understanding, for example Syi'ah / Syi'i or Ahmadiyah, or latest for example Salamullah, Bahaiyah, Inkarussunah and others. Not only is there a conflict of understanding between Sunnis and Shi'ites, even within Sunni and Shi'i circles, there are also conflicts of understanding between one another. For example, between Traditional Sunnis as represented by NU, Al Washliyah, Perti, Nahdlatul Wathan, Al Khairat and the Tariqat group with Modernist Sunnis who were presented with Muhammadiyah, Persis, and Al Irsyad. Or among the Shi'ites between the Shiite Imamiyah (Itsna Asy'ariyah) and Zaidiyah and other religious understandings.

If we trace the history of the existence of social understandings and conflicts that have accompanied the above religious ideas, it is found that there is a continual inheritance of 
contradictions between several Islamic religious schools, since their emergence in the central Islamic region (Middle East) and others, until later it spread to the rest of the Muslim world, including the Muslim periphery geographically, such as the Nusantara region. This eternal conflict can be observed in the conflict and conflict between Sunni and Shi'i ideas in Arabia, or the conflict between Sunnis and Ahmadis in the Indian subcontinent, or the contradiction of a number of other Islamic religious traditions in various parts of the Islamic world, such as the Sahara Africa and Central Asia.

In particular, the conflict between Sunnis and Shi'i has been going on since the first century of Islam, originating in the early days of the development of Islam in the Middle East, especially during the time of Khulafa ur Rashidin (Abu Bakr, Umar, Uthman, and Ali). Historical records inform, shortly after the death of Muhammad Rasulullah on 12 Rabi'ul Awwal, the XII H year (8 June 632M), which then raises a big question about who will succeed Rasulullah as the next leader of the Islamic ummah. This question arose among the Ansars. Feeling they had to choose a successor to the Prophet as their leader, the Ansar, who became the hosts in Medina, immediately gathered at the Saqifah Bani Sa'idah on the day the Prophet died, even though the Prophet's body was not yet buried. However, the meeting was discovered by a number of other friends of the Muhajirin, so immediately came to Saqifah Bani Sa'idah to attend this important meeting. The Muhajirin who came, was originally Umar bin Khattab who then asked Abu Bakr Ash Siddiq to come to that place at the same time. At the Saqifah Bani Sa'idah meeting, there was a heated debate over who had the right to replace Muhammad's position as religious leader and leader of the state. In the Saqifah incident, the Ansar wanted to take Sa'ad bin Ubadah as a substitute, but they did not choose, because of the arrival of Abu Bakr and Umar. After a while there was a debate between Ansar and Abu Bakr accompanied by Umar. After questioning each other, without thinking for a long time, Abu Bakr raised the hands of Umar and Ubaidah bin Jarrah and asked the participants of the meeting to pledge to one of them. However, Umar withdrew his hand, instead he turned around and raised his in-law's hand and took Abu Bakr by commenting "O Abu Bakr, didn't the Prophet tell you, so that you lead the Muslim prayer? You are his successor (caliph). We will make a pledge of the person most liked by Rasulullah of us all. The attitude of Umar touched the audience's feelings, then he committed allegiance to Abu Bakr. Haekal called this allegiance as the 'Pledge of Saqifah'. Then, on the 13th of Rabiul Awwal, when the Prophet's body was still not buried, it was followed by a 'public pledge' in front of the public, where this allegiance was preceded by the speech of Umar bin Khattab and pronouncing bai'at and calling the people to make a pledge to Abu Bakr. This action of Umar also caused oblique voices among the general people of Medina who were still grieving.

\section{Review of Literatures}

\subsection{Philosophy of Science}

The philosophy of science is a part of epistemology (philosophy of knowledge) which specifically examines the nature of science. Science is a branch of knowledge that has certain characteristics. Although methodologically science does not distinguish between natural science and social science, due to technical problems that are unique, the philosophy of science is often divided into the philosophy of the natural sciences and the philosophy of the social sciences. The philosophy of science contains an understanding of the ontological (existing), epistemological (knowledge) and axiological (value) of an object of study, so that it can be judged to meet the requirements as a science or not. Without these three instruments, an object of study does not meet the criteria to be called science. 


\subsection{Paradigm of Communication Studies}

Communication is the process of delivering messages by someone to other people to tell, change attitudes, opinions or behavior either directly orally or indirectly through the media. In this communication requires a reciprocal relationship between the delivery of messages and recipients namely communicators and communicants. (Hasbullah et al, 2018)

According to Aminullah (2018) the communication that developed during this explains about human relationships. Therefore, communication is conveying information or ideas rather than messengers to the recipient of the message, so that the recipient of the message will understand as understood by the messenger. While Nurdin (2019) Communication is one of the most important forms of human activity without days of communication. Every living thing needs communication because communication is a symbol of the existence of life in society.

Communication science, which is understood as a science, is also tied to the values of the philosophy of science in the areas of ontology, epistemology and axiology. Thus in the philosophy of communication science, at least must answer a number of basic philosophical questions. Ontologically, the philosophy of communication science must answer the question: What is communication science? What does the science of communication study? What is the object of study? What is the nature of communication science which is the object of his study?

Epistemologically, the philosophy of communication science answers the question of how is the process that allows knowledge to be transformed into science? What is the procedure and methodology? What are the things that should be considered in order to obtain correct knowledge and knowledge in communication? What is meant by truth? What are the criteria for truth and the logic of truth in the context of communication science?

\subsection{Intercultural Communication Model.}

Model is a systematic and abstract description, which describes certain potentials related to various aspects of a process (Book, 1980). There are also those who describe the model as a way to show an object in which it explains the complexity of a thought process and the relationships between the elements that support it. The model is built so that we are able to identify, and describe or categorize the relevant components of a process. A model can be said to be perfect, if it is able to show all the aspects that support a process. For example, it can perform specifications and show the relationship between one component and another component in a process and its existence can be demonstrated in real terms.

Models are generally used in the study of communication science, as a first step in theory development in the next process. In the model, the important elements of each existing component can be identified, then connected as a whole and show the process that occurs between one component and another, then forming a complete picture of an existing symptom or phenomenon. In intercultural communication, communication occurs between sources (sources) from the community of a culture with recipients (receivers) from different cultural communities. The meeting between the source and the recipient in certain situations and conditions for communicating will certainly cause problems when they communicate, for example in the encoding process and in the process of back-coding (decoding). 


\subsection{Islamic Communication}

The Qur'an as a basic guideline for Islamic teachings contains many basic ethics and principles in communication between humans, both interpersonal, interpersonal, group, organizational, intercultural, even communication between creatures on this earth. In relation to humans, the basic principles established by the Koran show the importance of communication as a tool for interaction with God and social interaction between fellow humans and fellow creatures of God's creation. There are many verses of the Koran that can be used as a basis and guide in communicating. Gratitude Kholil, for example, revealed that there are at least 54 surahs and 166 verses in the Koran that talk about communication or those related to communication. The verses referred to, namely Qs Al Baqarah (2): 25, 44, $83,113,127$,

Likewise, Qs At Taubah (9) is in verse: 70, then Qs Yunus (10) is found in verses: 64, 65, 69, and 71. Then Qs Hud (11), is in verse: 2, then Qs Ar Ra'du (13) verses: 2, and 10. Then Qs Ibrahim (14) there are verses: 4, 24, 25, 26. Furthermore, Qs An-Nahl (16) in verses: 35, 89, 90 and 125. Qs Al Isra (17) in verses: 9, 23, 36, and 53. In Q. s Al Kahfi (18) there are verses: 1, 2, 23, 24, and 56. In addition, in Qs Thaha (20) in verses: 25, 26, 27, 28 and 49. In Qs Al Anbiya (21) in verse: 45, then Qs Al Hajj (22) in verse: 30 and Qs Al Mukminun (23) verse: 3. Then Qs An -Nur (24) verses: 11, 12, 13, 14, 15, 16, 19, 22, and 25. In Qs Al Furqan (25) verses: 33, 63 and 63. Qs as Syu'ara (26) verse : 226. Then Qs An-Naml (27) in verses: 18, 19, 20, 21, 22, and 23. In Qs Al Ankabut (29) in verse: 18, and 46. Also Qs Luqman (31) is found in verses: 6,13,14, 15, 1617, 18, 19, and 27. Then in Q. s Al Ahzab (33) there are verses: 21, 32, 58. Then Qs Saba '(34) in verse: 34, Qs Fathir (35) verse: 24, Qs as Shaffat (37) verse: 10, 11, Qs As-Shad (38) verse: 86, Qs Az-Zumar (39) verses: 9 and 18. Furthermore, Qs Al Mukmin (40) verse: 66, Qs Fushilat (41) verses: 3, 4, 22, 33, 34, and 44.

Next Qs As-Shura (42) verse: 51, Qs Az-Zukhruf (43) verse: 3, 17, Qs Ad Dukhan (44) verse: 58, Qs Al Jasyiyah (45) verse: 7, Qs Al Ahqaf (46 ) verses: 12, 17 and 29. Furthermore, Qs Muhammad (47) verses: 16, 21, and 23. Then Qs Al Fath (48) verse: 8, Qs Al Hujurat (49) verse: 2, 3, 4, 6 , 11, and 12. Qs Al Qaf (51) verse: 45, Qs Az-Zariyat (51) verse: 55, Qs An-Najm (53) verses: 3, 4, and 59. Then Qs Ar Rahman (55) verses: 1, 2, 3, 4. Qs Al Mujadilah (58) verse: 1, 7, 8, 9, 10 and 12. Then Qs Al Munafiqun (63) verse: 4, Qs At-Thalaq (65) verse: 6, Qs At-Tahrim (66) verse: 3, Qs Al Mulk (67) verse: 13, Qs Noah (71) verse: 5, 6, 7, 8, 9, Qs Jin (72) verse: 4, and 5. Furthermore, Qs Al Muzammil (73) verse: 10.

\subsection{Model of Religious Communication}

The communication model that researchers design is a religious communication model which later tries to perfect or combine Kincaid and Rogers' participatory communication model and Porter and Samovar's intercultural communication model. Kincaid and Roger through their symbolic interactionist theory approach, in the strongest emphasis of the second model, is the importance of a tolerant attitude from each actor of communication, when they try to carry out social interactions between cultures. Meanwhile, Porter and Samovar emphasize the existence of the nature of intercultural communication related to homophiles (equations) and heteroviles (differences) between individuals and groups of actors of intercultural communication. The keywords of the two models of intercultural communication are tolerance, similarities and differences.

In the model of religious communication, it is described how individuals and socioreligious groups with different religious views / schools / sects can carry out harmonious, harmonious and civilized religious communication activities. If the process that occurs will be carried out using a religious model approach that the researcher intends to design later. $\mathrm{He}$ explained that in the course of history, a religion has become an inevitable reality. There must 
have been differences between individuals and socio-religious groups that exist in interpreting existing religious texts. Both the scriptural text and the context of religious traditions contained in religious processes over time, are caused by various factors, including psychological, political, social, economic and cultural as well as geography. As a result of that difference, the crucial point is that there is a split between followers of one religion and another, or fellow adherents of one religion, so as to give rise to an understanding / mazhab / sect. The emergence of understanding / mazhab / sect in a religion, in the subsequent historical process also gave birth to great contradictions, which often led to strong disputes, even wars that destroyed property and lost lives. However, according to the researcher, the contradiction has always been started by the absence of connectivity between one understanding / school of thought / sect. Connectivity has actually been understood as the non-occurrence or loss of the intensive and continuous communication process between understandings / mazhab / sects between religions and within one religion, due to various psychological, social, political, geographic and economic factors.

\section{Research Methods}

This research will start from the interpretive paradigm. In this paradigm view, human beings are "impossible not to communicate". Wilbur Schraam said, who carries this paradigm, it is impossible for humans not to communicate, even though they are in the middle of a big city crowd, and as if they are feeling lonely in that city. Big cities are very crowded with various activities from various people, and various brands of motorbikes are crowded the streets. But then why do some people feel lonely in the crowd of a city. One of them may be, because you do not know any of these busy people as friends, relatives, friends, or colleagues, especially if it is your first time setting foot in the City. However, still in the midst of such things, humans communicate.

Interpretive paradigm, seeks an understanding of how we shape the world of meaning through interaction and how we behave in our world to form a world of meaning through interaction and how we behave towards the world we form, so as to capture the intricacies, nuances and complexities of human interaction. In everyday life, as stated by Muller (2002), we are faced with the regularity and irregularity of communication interactions, the situations that occur may be ordinary (small) or extraordinary (large). We make choices about how best to talk to a supervisor about bad scores on an exam. We try to comment on the many commentators who discussed that day. In all those everyday situations.

\section{Results and Discussion}

So far, in social reality there has rarely even been a physical intensive dialogue between adherents of Sunni and Shi'i ideology, especially among the social middle and lower classes. In social media, the opposite happens, where dialogue can occur with a high duration regardless of social class, if the topics discussed bring together individuals and groups in the intended link (link) of the same kind. There are many links on social media that open opportunities for dialogue between the two ideologies referred to freely, without geographical, psychological or physical boundaries. Especially if the user really intends to find a topic he really wants through a search engine like Google. Many links on social media provide opportunities for encounters between Sunni individuals and groups with Shi'i individuals and groups, without having to know each other or have interacted socially. Besides, there is a continued discussion of factual reality to social media between individuals and between communities who have previously known each other. 
In addition, individuals and communities of social media users have the widest possible opportunity to express their religious understanding and receive the broadest possible reactions from others when they see these posts. A meaning that is far from dialogue also occurs on social media when the flow of propaganda in nature floods social media pages. Many links with group content propagate with the aim of perpetuating the assumptions that have existed in factual reality, that Shi'ism is deviant and Sunnis are deviant. Usually this group link is made by internal elements on both sides who have radical or extreme tendencies. Apart from that, there is also a group link created by the Sunnis but says it is a Shi'i group link, and vice versa.

Some of the dialogues that the researchers have observed, between Sunni-Shi'i supporters that occur on social media, end in blasphemy to insults between one another, and then just end up leaving an unhealthy impression on each one involved in the dialogue. Although it cannot be denied, there are also dialogues that end in an elegant and respectful manner, by generating new knowledge for connoisseurs of dialogue on social media. In this connection, the researcher took the events of the Sunni-Shi'i religious understanding that occurred on social media as an additional variable that resulted in blasphemy and stigmatization of their respective understandings. Another additional variable is the conflict that occurs between Sunni individuals and Shi'i individuals who are in one orbit of interest, namely at work.

\subsection{The Sunni-Shi'i Conflict between YAT and Journalists}

The first debate on social media (Facebook) that the researchers participated in was loud dialogue and tended to argue with coachmen and mutual blasphemy between Candiki Repantu (CR) and Edwin Dhani (ED). In CR's post, Sunday, November 19, 2017, at 3:00 p.m., then lasting a few days, the Chairman of the Abu Thalib Foundation, Medan, posted an event showing sympathy for Syi'i, resulting in dialogue with several other netters. As time went on, another netter named ED actually commented on the CR account, but it started with a reactive tone. At the next stage there was a dialogue with each other, where CR was supported by several other netters, defending himself from the harsh language raised by ED. The dialogue on Facebook's media runs wild, because the language used is sarcastic and ignores social media ethics. One of the languages used by ED in addressing the dialogue referred to, is uttering the sentence "misguided understanding laknatullah" against Shi'i understanding. In the view of netizens ED, Shi'i understanding is an understanding that divides Muslims from within, resulting in the weakness of Muslims throughout its history. The reason is that Shi'i often mislead Muslims when there are conflicts or clashes of civilization with enemies of Islam in various parts of the existing Islamic world. Syi'i is also seen by netizens ED, as an understanding that divides Muslims, through religious attitudes that tend to be fanatical, exaggerated and bid'ah in various religious matters. Seeing the loud dialogue, CR then stopped replying to ED's comments, However, the counter comments came from several other accounts which seemed to support CR's statement and blasphemed ED's views and personalities with the same weight of language violence. The dialogue on the CR account, had lasted several days, with a large capacity of blasphemy and was constant, but it just ended without a clear ending. 


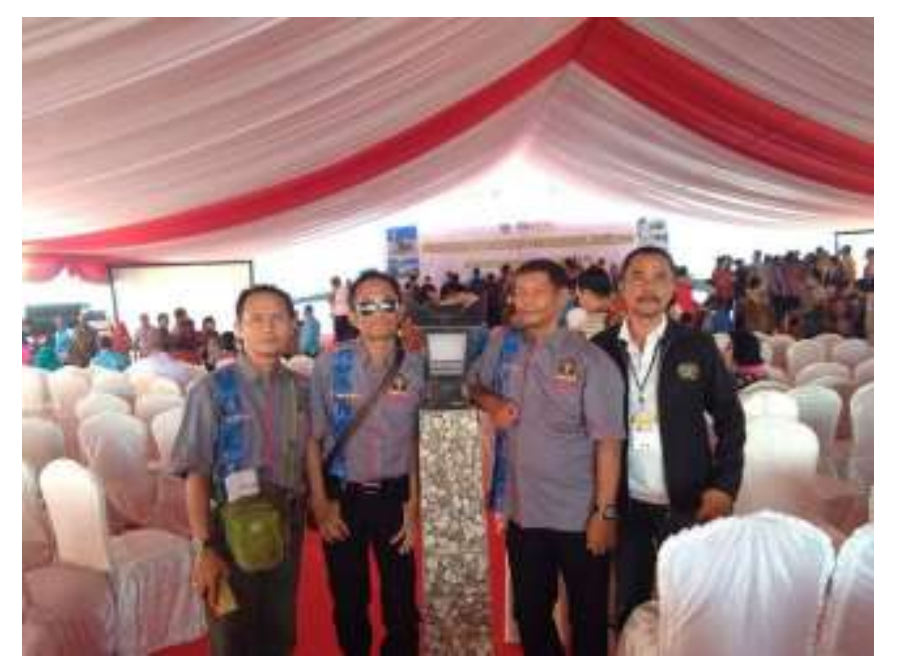

Figure 1. Caption: Afternoon News Journalist Informant Edwin Dhani (late) (second from left)

In connection with the conflict on social media, based on ED's confession when the researcher interviewed him, he had been doing this for more than 5 years, starting from 2015 by tracking various Shi'i group links and then registering as a member. After being registered, the main task he does is to object to the status of members who are considered to spread Shi'i understanding. Rebuttal itself, is not by following scientific narratives or using logic and religious arguments, but is only in the nature of confusing by using sarcastic language, blaspheming as well as dirty words. Later, activities stopped in mid-2019, because they were removed from the group link by the owner admin whom he had been with for several years. ED estimates, He was removed from membership in the Shi'i group link because other members could no longer have a healthy dialogue, or be invited to discuss in relation to Sunni-Shi'i religious issues. As far as he knows, several other members were also excluded from the membership of the Shi'i link group, because they were contrary to the general views of the members in that group. For example, there was a member named 'Jack' who had his address in Jakarta and claimed to be a former Shi'i, who was later also removed from the Syi'i group link. With a member named 'Jack', ED often supports each other in debates on the link group in question. A similar practice was also carried out by ED when interacting with CR on social media Facebook, so that at a certain point CR invited ED to visit the foundation he leads and discuss the issues they are debating. CR invited ED several times, but the invitation was not met. Likewise with a woman with a Shi'i understanding named Darmaila Wati (DW), ED had a hard debate. One of them debating is mawin muth'ah. ED even mocked the activist of the Abu Talib Foundation by asking him to marry muth'ah, but there was no response. DW did something similar to what CR did by inviting those concerned to attend and discussing at the Abu Thalib Foundation, Medan, but there was no response. Likewise with a woman with a Shi'i understanding named Darmaila Wati (DW), ED had a hard debate. One of them debating is mawin muth'ah. ED even mocked the activist of the Abu Talib Foundation by asking him to marry muth'ah, but there was no response. DW did something similar to what CR did by inviting those concerned to attend and discussing at the Abu Thalib Foundation, Medan, but there was no response. Likewise with a woman with a Shi'i understanding named Darmaila Wati (DW), ED had a hard debate. One of them debating is mawin muth'ah. ED even mocked the activist of the Abu Talib Foundation by asking him to marry muth'ah, but there was no response. DW did something similar to what CR did by inviting those concerned to attend and discussing at the Abu Thalib Foundation, Medan, but there was no response. 


\subsection{Sunni-Shi'i Conflict between Individuals in Tebingtinggi}

Apart from social media, conflicts also occur between Sunni individuals and Shi'i individuals. The conflict began when an individual with a Sunni view later found out that his colleague was in fact Shi'i. It's just that the conflict model based on the researchers' observations does not use verbal communication, but rather expressions and behaviors that indicate rejection of the religious understanding of fellow colleagues. The two research resource persons were teachers at a private university foundation in Tebingtinggi City. The two of them have worked at the foundation for decades, so they know each other and are relatively close. Until recently in 2016, a Sunni teacher named Hasrita Haizan (HH) knowing that his colleague, Gindo P. Batubara (GPB), has different religious beliefs with him. GPB, after changing its religious beliefs from Sunni to Syi'i, is indeed known as an open, more aggressive and seemingly offensive figure in showing its sincerity. To anyone of his coworkers, if there is an opportunity, always reveal about his loneliness. Not only that, GPB always builds an impression in front of his colleagues that Shi'is are better than Sunnis. Teacher of Indonesian Language Studies, alumni of the Faculty. USU's Cultural Studies, identifies itself as a member of the North Sumatra Ahlul Bait Indonesian Congregation Association (Ijabi). He stated that every month they take part in their group's taklim in Medan, by spending a certain amount of money for this activity. Not infrequently in interactions with fellow colleagues, he tends to blame if he thinks that something his colleague has done is not in accordance with his understanding. GPB itself among colleagues in private universities is seen as a cleric, so that in religious activities it becomes a carrier of religious prayer, but its role in religious activities is often a source of conflict among colleagues. One of the co-workers who rejects the religious role of GPB is HH. The form of rejection of GPB, is carried out starting from subtle ways to showing expressions of dislike for the co-workers he is aiming for. $\mathrm{HH}$ considered that his actions did not raise his hand when praying was led by GPB, because he considered the Shi'i ideology that his co-workers embraced was heretical and deviated from Islamic teachings so that his attitude not to raise his hand is deemed correct. Later, he also stopped addressing the person concerned, as he had done so far as a form of protest over the shift in his colleague's religious understanding.

In flag ceremonies, religious activities, as well as gathering at school, if the GPB brings prayers, then $\mathrm{HH}$ and some teachers who later know the difference in religious understanding between them, do not immediately raise their hands, as an expression of rejection of prayer sung by GPB. Not infrequently in committee activities, teachers who know about the movement of GPB from Sunni to Shi'i, refuse subtly if a role is given to those concerned. The culmination of the voiceless conflict was the unilateral isolation by teachers of GPB in relation to their relationships, starting from rarely talking to or traveling without including the person concerned and various other forms of isolation.

\subsection{Prejudice and Disruption of Harmonious Relationships}

The debates that occur among Sunni-Shi'i netters, as long as the researchers' observations, show that prejudice is getting stronger among them. Netter Edwin Dhani's refusal to the invitation of Candiki Repantu and Dharmaila Wati to visit the YAT Secretariat in Medan shows the absence of good will to know what and how Syi'i's existence so far. The debate on social media did not resolve existing prejudices, and even tended to be strengthened among Sunni netters. For netizens who are Shi'i, based on the observations of researchers, it also does not change the view so far that their community has been alienated from Muslims just because of differences in religious understanding. There is a tendency, Shi'i netters move away from Muslims and see themselves as no longer fellow Muslims, however, they are outside the Muslim community, so they try to build their own identity 
which tends to have behavior in cyberspace to be contrary to the behavior of Muslims with Sunni views, both socially, politically and economically. Another behavior that is carried out is, Shi'i netters gather in a group that is sterile from Sunni netters, so they do not see various phenomena and symptoms of religious communication that may occur outside their group in order to find comfort in the embrace of the understanding they believe in surfing in cyberspace. .

Harmonious relations are also disturbed in the world of work, as shown by the case of Sunni individuals and their communities with Shi'i individuals. Each of them builds social distance in relation to religious understanding, but unconsciously it also has an impact on social relations. The tendency to isolate Shi'i individuals from social interactions is the most factual form of the disharmony of social relations among teachers at the Taman Siswa College. The view of Sunni individuals supported by other teachers, that Shi'i is heretical / deviant in fact has changed their behavior to stay away, even the degree of change in behavior is far greater than their attitudes and behavior towards non-Muslim colleagues.

\section{Conclusion}

Since the beginning of their respective existence, religious communication between Sunni-Shi'is in North Sumatra has always experienced ups and downs in accordance with the existing context in the region. Following the fatwa from the Center, all Islamic organizations in North Sumatra, both NU, Muhammadiyah and Al Washliyah as the oldest Islamic organizations, as well as more recent Islamic organizations such as An Nas, which are Sunnah, agree to state that Shi'ism is a religious understanding. who are perverted / deviant. However, based on existing political trends, after the Reformation, slowly the views of Sunni Islamic Organizations began to shift. This shift in view also follows the fatwa of the leadership of the mass organizations at the central level, along with the constellation of religious relations in the Islamic world, even though the shift is taking place gradually. The more moderate NU argues that the non-ghulat Syi groups are not heretical, even though grassroots congregations still view all Shi'i ideas as deviant / deviant, because information does not spread quickly and evenly. Likewise with Muhammadiyah, where there has been a shift in thinking among organizational elites, that Shi'ism is not deviant, even Muhammadiyah has collaborated with various Shi'i organizations through muzakarah forums among the elite, unfortunately among grassroots congregations. , such thing has not yet had a significant impact on this heretical / deviant view. However, another fact that emerges is that when the views of many mainstream Islamic organizations began to experience a shift at least at the elite level, on the other hand the rejection of Shi'i ideology also strengthened. due to the dynamics of post-Reformation Shi'i religious activities that were felt. This reaction turned out to have led to the anti-Shi'i movement which organized itself in An Nas's forum. 


\section{References}

Alquranul Karim dan Terjemahannya.(2015). Departemen Agama, RI, Depok, Penerbit Sabiq.

Alquran Terjemah Tafsiriyah. (2012). Memahami Alquran Lebih Mudah, Cepat Dan Tepat, Kota Gede, Yogjakarta, Penerbit Ma'had An Nabawy.

Alquran Terjemah Perkata 'Al Huda' Dilengkapi Transliterasi Arab-Latin, Jilid 10, Departemen Agama RI, Semarang, Pustaka Karya Toha Putra, tanpa tahun

Al-'Isy, Yusuf. Dr. Dinasti Umawiyah. (2007). Sebuah Perjalanan Lengkap Tentang Peristiwa Yang Mengawali dan Mewarnai Dinasti Umawiyah. (Terj). Jakarta, Pustaka Al Kautsar, Cet.7.

Ar Rifai, Muhammad Nasib. (2011). Ringkasan Tafsir Ibnu Katsir (terj), Jakarta, Gema Insani Press.

Atjeh, Aboebakar. (2018). Sejarah Syiah di Nusantara, Bandung, Arsy Sega.

Ash Shalabi, Ali Muhammad. (2012). Prof. DR. Khawarij dan Syi'ah Dalam Timbangan Ahlu Sunnah wal Jama'ah (terj). Jakarta, Pustaka Al Kautsar.

Aminullah, M. (2018). Theory of Alamin (A Formation of Universal Communication Formula). Budapest International Research and Critics Institute-Journal (BIRCIJournal), 162-181.

al Qarni. (2008). 'Aidh, Tafsir Al Muyassar, Jilid 4 Juz 24-30, (Terj), Jakarta, Qishti Press, Cet. 1.

az Zuhaili. (2013). Wahbah, Prof. Dr. Tafsir Al Wasith, Al Qashash-An Nash, Jilid 3, (Terj.), Jakarta, Gema Insani Press.

Azra, Azyumardi. (2004). Jaringan Ulama Timur Tengah dan Kepulauan Nusantara Abad XVII \& XVIII, Bandung, Mizan.

Badara, Aris. (2013). Analisis Wacana, Teori, Metode, dan Penerapannya Dalam Media Massa, Jakarta, Kencana Pradana Media Group.

Berger, Cherles P, Rolof, Michael E, Roskos, Ewoldson, David R Roskos. (2014). Handbook Ilmu Komunikasi, (Terj). Jakarta, Bandung, Penerbit Nusa Media.

Buhairi. (2015). Syaikh Muhammad Abdul Athi, Tafsir Ayat-Ayat Ya Ayyuhal-Ladzina Amanu (Terj). Jakarta, Penerbit Al-Kautsar, Cet. 2.

Bungin, Burhan. (2011). Analisis Penelitian Kualitatif, Komunikasi, Ekonomi, Kebijakan Publik dan Ilmu Sosial Lainnya, Jakarta, Kencana.

-(2003) Analisis Data Penelitian Kualitatif, Pemahaman Filosofis dan Metodologis Ke Arah Penguasaan Model Aplikasi, (Jakarta, PT Raja Grafindo Persada).

Basarsyah II, T. Lukman Sinar. (2006). Bangun dan Runtuhnya Kerajaan Melayu di Sumatera Timur, Medan, Yayasan Kesultanan Serdang.

Cangara, Hafied. (2006). Pengantar Ilmu Komunikasi, Jakarta, PT RajaGrafindo Persada.

Chaniago, Andrinof A. (2012). Gagalnya Pembangunan, Membaca Ulang Keruntuhan Orde Baru. Jakarta, LP3ES.

Daymond \& Holloway. (2008). Riset Kualitatif Dalam Publik Relations dan Marketing Communication, (Terj), Yogjakarta, PT. Bentang Pustaka).

Effendy, Onong Uchjana. (2003). Ilmu, Teori dan Filsafat Komunikasi, Bandung, PT Citra Aditya Bhakti.

Enayat, Hamid. (1988). Reaksi Politik Sunni dan Syi'ah, Pemikiran Politik Islam Modern Menghadapi Abad ke-20, Bandung, Penerbit Pustaka.

Esposito, John L. (2007). Ensikplopedi Oxford, Dunia Islam Modern (Terj.). Bandung, Mizan, Jilid I, Cet. II. 
Gultom, Ibrahim. (2010). Agama Malim di Tanah Batak, Jakarta, PT Bumi

Aksara

Gulpaygani, Ali Rabbani. (2014). Kalam Islam, Kajian Teologi dan Isu-Isu Kemazhaban,Jakarta, Nur Al Huda, Cet. 1.

Hasbullah, et al. (2018). Communication Pattern of Wilayatul Hisbah, Lhokseumawe City in Implementing Amar Makruf Nahi Mungkar. Budapest International Research and Critics Institute-Journal (BIRCI-Journal). P. 194-205

Jalaluddin, Rakhmat. (1991). Islam Aktual, Bandung, Mizan.

Jamaluddin, M. Amin. (2012). Kesesatan Akidah dan Ajaran Syiah di Indonesia, Jakarta, DDII.

Little John and Fox in Morissan. (2012). Teori Komunikasi, Individu Hingga Massa, Jakarta, Prenada Media Group.

Loeb, Edwin M, Sumatera. (2019). Sejarah dan Masyarakatnya, (terj.), Yogjakarta, Penerbit Ombak.

Lubis, Ali Hasan. (2019). Muhammadiyah Kota Tebingtinggi Dari Periode Ke Periode, Surabaya, Media Guru.

Kholil, Syukur. (2007). Komunikasi Islam, Bandung, Cipta Pusaka Media.

Koentjaraningrat. (2015). Kebudayaan Mentalitas dan Pembangunan, Jakarta, PT Gramedia Pustaka Utama, (Cet.20).

MUI Pusat, Tim Penulis. (2013). Mengenal \& Mewaspadai Penyimpangan Syi'ah Di Indonesia. Jakarta, Nashirussanah, Cet. 2.

Mulyana, Deddy, dan Rakhmat, Jalaluddin, (ed.). (2009). Komunikasi Antar Budaya, Panduan Berkomunikasi Dengan Orang-Orang Berbeda Budaya, Bandung PT Remaja Rosda Karya, Cet.11.

Musbikin, Imam. (2013). Studi Islam Kawasan, Pergumulan Islam Dengan Budaya Lokal. Pekan Baru, Zanafa Publishing, Cet.1.

Nugroho, Joko Irawan. (2010). Majapahit, Peradaban Maritim. Ketika Nusantara Menjadi Pengendali Pelabuhan Dunia. Jakarta, Yayasan Suluh Nusantara Bakti.

Nurdin, Z. (2019). Commitment of Political Communication in the Mayor of Banda Aceh, Indonesia. Britain International of Humanties and Social Sciences (BIoHS) Journal, 3543.

Rahmadan, Agus Abdul. (2014). Psikologi Sosial, Integrasi Pengetahuan Wahyu dan Pengetahuan Empirik. Jakarta, PT Raja Grafindo Persada, Cet. II.

Rakhmat, Jalaluddin. (1991). Islam Aktual, Bandung, Mizan, Cet. 2.

Ricoeur, Paul. (2014). Teori Interpretasi, Membelah Makna Dalam Anatomi Teks, (Terj.), Yogjakarta, IRCiSod.

Rasyidi. (1986). Apa Itu Syi’ah? Jakarta, Harian Umum Pelita.

Rusydi, Syeikh Ahmad. (2013). Syi'ah dan Tarekat Sufi, Dua Sisi Mata Uang, (Terj). Jakarta, Pustaka Al Kautsar.

Saefullah Ujang. (2007). Kapita Selekta Komunikasi, Pendekatan Budaya dan Agama, Bandung, Simbiosa Rekatama Media.

Sugiyono. (2012). Metode Penelitian Kuantitatif, Kualitatif dan R\&D. Bandung, Alfabeta.

Sumut, FKUB, Profil Forum Kerukunan Umat Beragama Provinsi Sumatera Utara, Medan, Tanpa Tahun.

Syahputra, Iswandi. (2007). Komunikasi Profetik, Konsep dan Pendekatan, Bandung, Simbiosa Rekatama.

Sjarifoedin Tj.A, Amir. (2011). Minangkabau Dari Dinasti Iskandar Muda Sampai Tuanku Imam Bonjol, Jakarta, PT Gria Media Prima.

Syamhudi, M. Hasyim. (2015). Akhlak Tasawuf Dalam Konstruksi Piramida Ilmu Islam, Malang, Madani Media. 
Syari'ati, Ali. (2003). Kemuliaan Mati Syahid. Jakarta, Pustaka Zahra, Cet. I.

Taufik, Tata. (2012). Etika Komunikasi Islam, Bandung, Pustaka Setia.

Ulum, Bahrul dan Husaini, Adian, (ed.). (2017). Kritik dan Solusi Syiah di Indonesia, Jakarta, Penerbit Republika.

Quthb, Sayyid. (2003). Tafsir Fii Zhilalil Qur'an, Surah At-Taubah 93-Yusuf 101, Jilid 6, (Terj). Jakarta, Gema Insani Pres.

Vardiyansyah, Dani. (2005). Filsafat Komunikasi, Suatu Pengantar, Jakarta, Gramedia.

Venus, Antar. (2009). Filsafat Komunikasi Orang Melayu, Bandung, Simbiosa Rekatama Media.

Virkler, Henry A, and Ayayo. (2015). Karelynne Gerber, Hermeneutik, Prinsip-Prinsip dan Interpretasi Alkitabiah, (Terj.) Yogjakarta, Penerbit ANDI.

Zar, Sirajuddin. (2009). Filsafat Islam Filosof dan Filsafatnya, Jakarta, PR RajaGrafindo Persada. 